sciendo Порівняльна професійна педагогіка 9(1)/2019 Comparative Professional Pedagogy 9(1)/2019

DOI: $10.2478 /$ rpp-2019-0005

PhD in Pedagogy, Associate Professor, TETIANA ZOROCHKINA Bohdan Khmelnytskyi Cherkasy National University Address: 81 Shevchenko Blvd, Cherkasy, 18031, Ukraine

E-mail: zvezdochcina@gmail.com

\title{
FINANCIAL SUPPORT OF HIGHER EDUCATION DEVELOPMENT IN UKRAINE AND THE UK
}

\begin{abstract}
The article deals with the financial support of higher education development in Ukraine and the UK. It presents the expenditure of the consolidated budget on education between 2007 and 2017 in Ukraine and the expenditure on education services per student in the UK. It highlights the funding of research in higher education in Ukraine. It describes the personnel potential of higher education institutions in Ukraine. It specifies the existing problems in the research sector of higher education in Ukraine. It indicates that research activities of the UK universities are at a high level since about one-third of research done by the UK universities is regarded as leading in the context of the world's research community. The article also considers the salaries of teachers and lecturers in different regions of the UK. Based on theoretical analysis of scientific and pedagogical sources one can conclude that teacher salary in the UK is quite high and differentiated. In addition, they employ other ways to differentiate teacher salary there. Indeed, teachers receive praise for their own professional growth and practice through a dialogue with their leader. It is found that the UK universities receive financial support from the funds administered by the Higher Education Funding Council for England (HEFCE) (except for colleges of further education). The expenditure on higher education per student in the UK is significantly higher than that in Ukraine. Due to the fact that salary differentiation stimulates teacher work, this important indicator must be implemented in Ukraine.
\end{abstract}

Keywords: financial support, higher education, Ukraine, the UK, university.

\section{АНОТАЦІЯ}

У статті розглядається фінансове забезпечення розвитку вищої освіти в Украӥні і Великій Британії. Показано витрати зведеного бюджету на освіту упродовж тривалого часу (2007-2017 рр.) в Украӥні та витрати на послуги у сфері освіти на 1 студента у Великій Британії. Висвітлено фінансування наукових і науково-технічних робіт у секторі вищої освіти Украйни. Описано кадровий потениіал $3 В О$ Украйни. Відмічено проблеми у секторі науки вищої школи Украӥни. На високому рівні представлена наукова робота у ЗВО Великої Британії приблизно одна третина дослідниџької діяльності, проведеної британськими університетами, вважається провідною у світі в галузі дослідницької компетенції. Розглянуто посадові оклади вчителів, викладачів у різних регіонах Великої Британії. Аналіз науково-педагогічних джерел дав можливість зробити висновки, що педагогічна зарплата у Сполученому Королівстві досить висока $i$ диференційована. До того ж, можна навести і інші варіанти диферениіаџії зарплати вчителів Великої Британії. Таким чином, вчителі отримують оиінку власного професійного зростання та практики у діалозі з йх керівником. 3'ясовано, що університети Великої Британії отримують фінансову підтримку з фондів, що управляються Радою 3 
sciendo Порівняльна професійна педагогіка 9(1)/2019 Comparative Professional Pedagogy 9(1)/2019

фінансування вищої освіти в Англії (НЕFCE) (крім коледжів подальшої освіти). Витрати на вищу освіту на одного студента за ПКС за функиіями у Великій Британії значно вищі, ніж в Україні. У зв'язку з тим, щчо диференціація зарплати стимулює роботу вчителя, цей важливий індикатор потрібно впроваджувати в Украӥні.

Ключові слова: фінансове забезпечення, вища освіта, Украӥна, Велика Британія, університет.

\section{INTRODUCTION}

Nowadays, Ukraine is facing significant problems with conducting effective research and innovation policy. The scientific research sector has sharply deteriorated in recent years: the volume of orders for scientific and technical products has been reduced; the personnel and material resources of research and development have decreased; the performance of science itself has decreased sharply. Therefore, one of the priority trends in reforming the national system of higher education in Ukraine is to reform its economic principles aimed at optimizing the use of such funds and creating transparent financial and economic mechanisms for targeted accumulation and targeted use of funds necessary for the full implementation of the constitutional rights of citizens to higher education (Stratehiia reformuvannia, 2014).

THE AIM OF THE STUDY

The aim of the study is to analyze financial support of higher education development in Ukraine and the UK.

\section{THEORETICAL FRAMEWORK AND RESEARCH METHODS}

The development of higher education in Ukraine and the UK was highlighted by N. Avshenyuk, Yu. Alforova, H. Andreieva, N. Bidyuk, Yu. Kishchenko, T. Kuchai, D. Kvasnychkova, H. Marchenko, O. Matviienko, Y. Poliakova, O. Romanova, I. Rudkovska, I. Zadorozhna et al.

Between 2000 and 2011, Ukraine reduced its share of expenditure on equipment, construction and modernization in the overall structure of expenditure on higher education from $17 \%$ to $4 \%$, whereas the neighbouring countries of Central Europe continued to increase it: the Czech Republic (up to $20 \%$ ), Poland (up to $22 \%$ ) and Lithuania (up to $25 \%$ ). Between 2012 and 2013, the expenditure on higher education in Ukraine slightly increased. After 2013, however, the expenditure in real terms (in 2007 prices) on higher and postgraduate education sharply decreased (Stadnyi, 2015).

The consolidated budget expenditure on education in Ukraine between 2007 and 2017 is presented in Table. 1.

The data presented in Table 1 prove the following: the consolidated budget expenditure on education (in UAH million) increased in Ukraine between 2000 and 2018; total expenditure and GDP somewhat increased until 2010 and significantly decreased between 2015 to 2017 (Vyshcha osvita, 2018).

In the UK, a university is an institution designated to receive support from the funds administered by the HEFCE. Currently, all British higher education institutions, with the exception of Buckingham University and the University of Law, receive support from the funds managed by the HEFCE. Thus, the HEFCE directly funds 128 higher education institutions.

The total number of students for the higher education sector is planned by the Government and the HEFCE. Based on the proposals of the Government, the HEFCE sets a ceiling for the number of students each institution can accept. It enables the Government to monitor the level of publicly funded government student loans, grants and maintenance 
sciendo Порівняльна професійна педагогіка 9(1)/2019 Comparative Professional Pedagogy 9(1)/2019

grants. Not all students are entitled to represent the boards monitoring the number of students. Given the Government's aim to encourage popular and successful universities and colleges to expand and improve students' choices, universities and colleges are allowed to accept as many high-level students (currently ABB or higher at level A and equivalent qualifications) as they wish outside the monitoring of their number.

Table 1

The consolidated budget expenditure on education between 2007 and 2017

\begin{tabular}{|l|c|c|c|}
\hline \multirow{2}{*}{ Years } & Total expenditure of & \multicolumn{2}{|c|}{ Expenditure (\%) } \\
\cline { 3 - 4 } & consolidated budget, million & Total & \multirow{2}{*}{ GDP } \\
\cline { 3 - 4 } & UAH & 100.0 & 100.0 \\
\hline 2000 & 48148.6 & 14.7 & 4.2 \\
Total on education, & 7085.5 & 4.7 & 1.3 \\
\hline including higher education & 2285.5 & 100.0 & 100.0 \\
\hline 2005 & 141989.5 & 18.1 & 6.1 \\
Total on education, & 26801.8 & 4.7 & 1.8 \\
including higher education & 7934.1 & 100.0 & 100.0 \\
\hline 2010 (1) & 377842.8 & 21.1 & 7.4 \\
Total on education, & 79826.0 & 6.6 & 2.3 \\
including higher education & 24998.4 & 100.0 & 100.0 \\
\hline 2015 (2) & 679871.4 & 16.8 & 5.7 \\
Total on education, & 114193.5 & 4.6 & 1.6 \\
including higher education & 30981,8 & 100.0 & 100.0 \\
\hline 2016 (2) & 835832.1 & 15.5 & 5.4 \\
Total on education, & 129437.7 & 4.2 & 1.5 \\
including higher education & 35233.6 & 100.0 & \\
\hline 2017 (2,3) & 1056759.9 & 16.8 & $\ldots$ \\
Total on education, & 177755.7 & 3.7 & \\
including higher education & 38681.1 & & \\
\hline
\end{tabular}

In the UK, four higher education organizations fund the Higher Education Academy (HEA), which supports the community of higher education to enhance the quality and effectiveness of teaching and learning. The HEA provides academic staff with professional recognition, creates networking and provides development opportunities, as well as advice and support, including by collaborating directly with higher education institutions to understand their missions and priorities (England Higher Education System, 2014; Higher Education Funding Council for England, 2018).

Expenditure on higher education per student (in US dollars, as of 2009)

in the UK and Ukraine

\begin{tabular}{|l|c|c|}
\hline \multicolumn{1}{|c|}{ Category } & The UK & Ukraine \\
\hline Education services & 8367.9 & 3504.0 \\
\hline Secondary activities & 1520.8 & 570.9 \\
\hline Research & 6449.3 & not avail. \\
\hline Total & 16338.0 & 4074.9 \\
\hline
\end{tabular}


The data presented in Table 1 show that the expenditure on education services per student in the UK is 2.4 times higher than that in Ukraine and the expenditure on secondary activities -2.7 times. In the UK, the total expenditure per student exceeds that in Ukraine by 4.1 times. Consequently, the expenditure on higher education per student in the UK is much higher than that in Ukraine.

World university rankings are largely determined by the volumes and results of scientific research.

\section{RESULTS}

As evidenced by the mentioned above, Ukraine is facing significant problems with conducting effective research and innovation policy. The scientific research sector has sharply deteriorated in recent years: the volume of orders for scientific and technical products has been reduced; the personnel and material resources of research and development have decreased; the performance of science itself has decreased sharply. Some researchers largely attribute this to a change in financial support of science (see Table 2). In 2013 , the share of total expenditure in GDP was equal to $0.77 \%$, including $0.33 \%$ at the expense of the state budget.

The data presented in Table 3 indicate the funding of research in the sector of higher education in Ukraine.

Funding of research in higher education in Ukraine by sources of funding (million UAH)

\begin{tabular}{|l|c|c|c|c|c|c|c|}
\hline \multicolumn{1}{|c|}{ Category } & 2000 & 2005 & 2009 & 2010 & 2011 & 2012 & 2013 \\
\hline Total & 102.8 & 243.7 & 511.9 & 565.1 & 608.0 & 729.8 & 688.1 \\
\hline Budget funds & 58.0 & 139.0 & 338.1 & 411.6 & 432.9 & 514.9 & 472.1 \\
\hline Including the state budget & 58.0 & 135.6 & 335.0 & 387.9 & 402.3 & 483.4 & 438.5 \\
\hline Special purpose funds & 0.7 & 2.5 & 9.2 & 9.5 & 8.0 & 13.6 & 10.6 \\
\hline Own funds & 0.9 & 3.4 & 17.6 & 11.8 & 12.1 & 14.6 & 17.4 \\
\hline $\begin{array}{l}\text { Funds of customer } \\
\text { enterprises and } \\
\text { organizations of Ukraine }\end{array}$ & 36.5 & 78.2 & 94.0 & 110.0 & 124.5 & 152.2 & 154.9 \\
\hline Foreign funds & 5.3 & 8.9 & 23.1 & 18.6 & 25.5 & 30.5 & 29.3 \\
\hline Other funds & 1.4 & 11.7 & 29.8 & 3.5 & 4.9 & 4.1 & 3.7 \\
\hline
\end{tabular}

According to Table 3, the sector of higher education received 688057.6 UAH of research funding ( $6.1 \%$ of all expenditure on science) in 2013 , the bulk of which came from the state budget -438476.5 UAH (Stratehiia reformuvannia, 2014).

Given the current state of the Ukrainian economy, the increase in expenditure on higher education from the state budget is not expected in the coming years. In Ukraine, a significant indicator of education development is its personnel potential (see Table 4).

According to Table 4, the number of institutions preparing $\mathrm{PhD}$ students decreased from 513 to 475 (by 38 institutions) between 2010 and 2017. The number of institutions preparing postdoctoral researchers increased by 22 institutions (from 255 to 277) for the mentioned period. Regarding the preparation of research personnel, it must be noted that there were some tendencies towards reducing the number of $\mathrm{PhD}$ students from 33.739 individuals in 2010 to 24.780 individuals in 2017 and increasing the number of postdoctoral researchers from 1532 individuals in 2010 to 1821 individuals in 2015. In addition, one can observe a decrease in the number of postdoctoral researchers (in 2016-1.792 individuals, 
sciendo Порівняльна професійна педагогіка 9(1)/2019 Comparative Professional Pedagogy 9(1)/2019

in $2017-1.646$ individuals). This constitutes a relative number of 129.383 practising lecturers in higher education institutions in Ukraine.

Table 4

Personnel potential of higher education institutions in Ukraine

\begin{tabular}{|c|c|c|c|c|c|c|c|c|}
\hline Category & 2010 & 2011 & 2012 & 2013 & 2014 & 2015 & 2016 & 2017 \\
\hline $\begin{array}{l}\text { The number of postdoctoral } \\
\text { researchers, including } \\
\text { in pedagogy }\end{array}$ & 1532 & 1598 & 1776 & 1795 & 1759 & 1821 & 1792 & $\begin{array}{c}1646 \\
58\end{array}$ \\
\hline $\begin{array}{l}\text { The number of } \mathrm{PhD} \\
\text { students, including } \\
\text { in pedagogy }\end{array}$ & 33739 & 33321 & 32805 & 30740 & 27622 & 28487 & 25963 & $\begin{array}{c}24780 \\
877\end{array}$ \\
\hline $\begin{array}{l}\text { The number of lecturers, } \\
\text { including the Ministry } \\
\text { of Education and Science } \\
\text { of Ukraine }\end{array}$ & & & & & & & & $\begin{array}{c}129383 \\
90976\end{array}$ \\
\hline $\begin{array}{l}\text { The number of institutions } \\
\text { preparing } \mathrm{PhD} \text { students, } \\
\text { including in pedagogy }\end{array}$ & 513 & 507 & 504 & 502 & 482 & 490 & 481 & $\begin{array}{c}475 \\
76\end{array}$ \\
\hline $\begin{array}{l}\text { The number of institutions } \\
\text { preparing postdoctoral } \\
\text { researchers, including } \\
\text { in pedagogy }\end{array}$ & 255 & 257 & 264 & 267 & 264 & 283 & 282 & $\begin{array}{c}277 \\
38\end{array}$ \\
\hline
\end{tabular}

The overwhelming majority of academic staff studies at the expense of the state. Under modern conditions, the state has a complex of significant social and financial guarantees to holders of doctoral degrees and academic titles. According to the Decree of the Cabinet of Ministers of Ukraine as of August 30, 2002 No 1298 "On the Remuneration Based on the Unified Tariff and Coefficients for the Remuneration in Establishments, Institutions and Organizations of Certain Branches of the Budgetary Sphere", additional fees were set for the following academic titles: full professor $-33 \%$; senior lecturer, senior researcher $-25 \%$; for the following doctoral degrees: postdoctoral researcher $-25 \%$; doctor of philosophy - $15 \%$ (in the maximum amount of official salary (salary rates)) (Stratehiia reformuvannia, 2014).

In Ukraine, the research sector of higher education is facing the following problems:

1. The decrease in funding. Thus, the average cost of conducting research in the sector of higher education amounted to $29500 \mathrm{UAH}$ per year $(36.5 \%$ of the expenditure on R\&D per country) in 2005, 54400 UAH (38.2 \%) - in 2009; 61200 UAH (35.4\%) - in 2010; 71900 UAH (36.2 \%) - in 2012.

2. The low participation of Ukrainian researchers in international research. The share of funding for research institutions in the total amount of R\&D funding at the expense of foreign countries is negligible $-1.1 \%$ (2000), $0.7 \%$ (2005), $1.3 \%$ (2009); $0.8 \%$ (2010), $1.5 \%(2011)$ and $1.2 \%$ (2013) of the total funding of Ukrainian science at the expense of foreign countries.

3. They do not implement research-based training.

4. There are significant complaints of employers about the quality of specialist training (Stratehiia reformuvannia, 2014). 
Despite the above-mentioned problems, the total number of lecturers' printed work is steadily increasing: from 271.649 in 2011 (78.7 \% of the total number of scientific publications) to 303.192 in $2012(80.9 \%)$ and 320.166 in 2013 (81.8\%).

Research activities of the UK universities are at a high level since about one-third of research done by the UK universities is regarded as leading in the context of the world's research community. It must be noted that the studies from 154 British universities have been peer-reviewed by British and international research experts and only 6975 of them have been regarded as influential. The share of case studies recognized as such amounted to $44 \%$ and another $40 \%$ were recognized as being rather significant.

Studies show that the influence of research in UK universities is global. Higher education institutions had a lower income from research in 2015-2016 in comparison with the previous year. However, this decrease is due to the reduced expenditure on R\&D from HM revenue and custom. In British universities, the total income from research at the expense of grants and contracts has decreased by $1.8 \%$ (GBP 90 million) and in real terms up to GBP 4.8 billion.

The Research and Development Expenditure Credit (RDEC) offers tax incentives to large companies to encourage greater investment in R\&D. Between 2014 and 2015, it provided USD 436 million to higher education institutions and between 2015 and 2016 only USD 82 million. This is because universities and charitable organizations have become unfit for the RDEC since August 1, 2015 (Tragner, 2017). With the exception of the RDEC, the real term of the annual increase in research revenue amounted to $5.9 \%$ or GBP 264 million between 2015 and 2016. Research councils remained the single largest source of research revenue between 2015 and 2016. In particular, their revenues increased by $6.9 \%$ (GBP 102 million).

Britain's charity was the largest proportionate increase in research funding between 2015 and 2016. Grants and contractual revenues from this source increased by $11 \%$ (GBP 96 million). Compared to the previous year, EU funding increased by $0.9 \%$ (GBP 6 million) between 2015 and 2016 (Higher Education Funding Council for England, 2018).

Thus, the UK research sector has the following achievements: research is funded by the RDES, research councils and Britain's charity; higher education institutes take an active part in international research whose influence is rather global; higher education institutions have revenues from research; training is realized based on research in which students are involved.

In Ukraine, the most relevant issue of higher education is the low status of lecturers which is traditionally combined with the level of salary. Indeed, if lecturers and teachers receive a higher-than-average salary, the education system will be regarded as prestigious employment (Stratehiia reformuvannia, 2014). Therefore, an important indicator characterizing the education process of general secondary education is salaries of Ukrainian educators which remain lower than that in the developed OECD countries. In 2012, the basic salary of a novice teacher in Ukraine amounted to $1708.8 \mathrm{UAH}$; of an experienced teacher (10-15 years of work experience) - $1993 \mathrm{UAH}$; of a methodologist teacher - $2136 \mathrm{UAH}$. With regard to the average monthly salary (2810 UAH) in the country, a master of arts in education receives $3726 \mathrm{UAH}$.

For comparison, the salary is converted into US dollars. According to it, the basic yearly salary of a Ukrainian teacher varies from 6531 USD for a novice teacher (based on PPP) to 8189 USD for a methodologist teacher. This, in turn, indicates a certain equalization of pay levels which negatively affects Ukrainian teachers' striving for professional development. 
sciendo Порівняльна професійна педагогіка 9(1)/2019 Comparative Professional Pedagogy 9(1)/2019

In most OECD countries, the gap between the maximum and the starting salary of teachers is higher than that in Ukraine. In England in 2012, the official annual salary of teachers with 15 years of work experience and those with minimum qualifications in England was 7.5 times higher than that in Ukraine (Stratehiia reformuvannia, 2014; Vashchenko, Kupets, Likarchuk, \& Sydorenko, 2012). As L. Vashchenko, O. Kupets, I. Likarchuk, \& M. Sydorenko (2012) note, low salaries and lack of prospects for improving the financial situation in Ukraine are the main factors in teachers' emigration abroad.

In the UK (England, Wales), teachers used to receive an annual increase in salaries almost automatically. Since 2014, the salaries have been increased depending on their effectiveness. In the UK, the education system is characterized by the fact that the ratio of salary increase is higher than that in the EU. In England, the ratio of salary increase is equal to $6.09 \%$ and is related to performance efficiency. Northern Ireland has maintained a system according to which teachers' salaries annually progress based on the main scheme of salaries (European Commission, 2015).

Table 5 presents the salaries of teachers and lecturers in different regions of the UK.

Table 5

\begin{tabular}{|c|c|c|c|c|c|}
\hline \multicolumn{6}{|c|}{ Teacher salary throughout the UK (between 2} \\
\hline \multicolumn{2}{|c|}{ Scale of payments } & $\begin{array}{l}\text { England, } \\
\text { Wales }\end{array}$ & London & Scotland & $\begin{array}{l}\text { Northern } \\
\text { Ireland }\end{array}$ \\
\hline \multicolumn{2}{|c|}{$\begin{array}{l}\text { Minimal salary of novice } \\
\text { teacher }\end{array}$} & $22917 £-28660 £$ & & $22416 £$ & $22022 £$ \\
\hline \multicolumn{2}{|c|}{ Unqualified teacher salary } & $16626 £-26295 £$ & $\begin{array}{l}17626 £- \\
30295 £\end{array}$ & & $14010 £$ \\
\hline \multicolumn{2}{|c|}{ Qualified teacher salary } & $22917 £-38633 £$ & $\begin{array}{c}24018 £- \\
39725 £ \\
\text { External: } \\
26662 £- \\
42498 £ \\
\text { Internal: } \\
28660 £- \\
47298 £\end{array}$ & $\begin{array}{l}22416 £- \\
43845 £\end{array}$ & $\begin{array}{l}22022 £- \\
37495 £\end{array}$ \\
\hline \multicolumn{2}{|c|}{ School principal salary } & $\begin{array}{l}44544 £- \\
109366 £\end{array}$ & $\begin{array}{l}45633 £- \\
116738 £\end{array}$ & $\begin{array}{l}42360 £- \\
86319 £\end{array}$ & $\begin{array}{l}38214 £- \\
107209 £\end{array}$ \\
\hline \multirow{3}{*}{$\begin{array}{l}\text { Higher } \\
\text { education } \\
\text { faculty }\end{array}$} & Lecturer & \multicolumn{4}{|c|}{$33943 £-41709 £$} \\
\hline & $\begin{array}{l}\text { Associate } \\
\text { Professor }\end{array}$ & \multicolumn{4}{|c|}{$41709 £-55998 £$} \\
\hline & Full professor & \multicolumn{4}{|c|}{$54637 £-107244 £$} \\
\hline
\end{tabular}

Systematized based on the following sources (Vyshcha osvita, 2018; Vashchenko, Kupets, Likarchuk, \& Sydorenko, 2012; Kaleniuk, 2013). 
sciendo Порівняльна професійна педагогіка 9(1)/2019 Comparative Professional Pedagogy 9(1)/2019

Table 5 proves that the scale of payments to teachers and lecturers is presented at such levels as the initial stage and the probation period.

In England and Wales between 2017 and 2018, the probation period salary ranged from 22917 to $28660 \mathrm{GBP}$, depending on the location (London and its area offer higher salaries). In Scotland, it amounted to 22416 GBP and 22022 GBP - in Northern Ireland. After the probation period, teacher salary increases according to the quality of work. Unqualified teacher salary is designated to those teachers who have not yet received QTS status (Vyshcha osvita, 2018). Qualified teacher salary varies between the UK countries: England and Wales - from 22917 to 38633 GBP; London - from 24018 to 39725 GBP, from 26662 to 42498 GBP (external), from 28660 to 47248 GBP (internal); Scotland from 22416 to 43845 GBP; Northern Ireland - from 22022 to 37495 GBP.

It must be noted that teachers who demonstrate outstanding results can apply for a post of a leading practitioner since the latter receives a much higher salary.

In the UK, the highest salaries are designated to school principals, namely England and Wales - from 44544 to 109366 GBP; London - from 45633 to 116738 GBP; Scotland from 42360 to 86319 GBP; Northern Ireland - from 38214 to 107209 GBP and higher education faculty ranging from 33943 to 107244 GBP (European Commission, 2015).

Public schools have also established the following payment rates: pay by age and number of children enrolled in an institution. Since work is not guaranteed throughout the year, many teachers receive their salaries at a daily rate, which is calculated proportionally, dividing the employee's annual salary by 195 (the number of days the teacher needs to be at school per year) (Knowles, 2018).

Based on the mentioned above, it must be noted that the UK universities receive financial support from the funds administered by the HEFCE (except for colleges of further education). The expenditure on higher education per student in the UK is significantly higher than that in Ukraine.

\section{CONCLUSIONS}

Therefore, theoretical analysis of scientific and pedagogical sources shows that teacher salary in the UK is quite high and differentiated. In addition, they employ other ways to differentiate the teacher salary there. Thus, London teachers can expect higher salaries than those within the London area (up to 46829 GBP per year). Salary rates for Scottish teachers vary depending on the length of service. In Scotland, educational leaders conduct an annual professional examination and organize meetings with lecturers during which they discuss a career-long professional learning plan (CLPL) based on the evaluation of needs. Indeed, teachers receive praise for their own professional growth and practice through a dialogue with their leader. Due to the fact that salary differentiation stimulates teacher work, this important indicator must be implemented in Ukraine.

The prospects for further studies include studying the features of initial teacher training in the UK so as to define the professional duties novice teachers should perform.

\section{REFERENCES}

1. England Higher Education System. (2014). Retrieved from http://www.euroeducation. net/prof/ukco.htm.

2. European Commission. (2015). The teaching profession in Europe. Practices, perceptions and policies. Eurydice Report. Retrieved from http://eacea.ec.europa.eu/education/ eurydice/documents/thematic_reports/184EN.pdf. 
3. Higher Education Funding Council for England. (2018). Retrieved from http://www.hefce.ac.uk/analysis/HEinEngland/.

4. Kaleniuk, I. S. (2013). Rozvytok vyshchoi osvity v hlobalizovanomu sviti. Innovatsiinyi rozvytok vyshchoi osvity. Cherkasy: B. Khmelnytsyi Cherkasy National University.

5. Knowles, E. (2018). How much do teachers get paid? Retrieved from https://www.prospects.ac.uk/jobs-and-work-experience/job-sectors/teacher-training-andeducation/how-much-do-teachers-get-paid.

6. Stadnyi, Ye. (2015). Osvita v Ukraini. Analitychnyi tsentr CEDOS. Vziato z https://cedos.org.ua/uk?page $=17$.

7. Stratehiia reformuvannia vyshchoi osvity v Ukraini do 2020 roku (proekt rozrobleno Robochoiu hrupoiu pid kerivnytstvom MON Ukrainy). (2014). Vziato z http://osvita.ua/ doc/files/news/438/43883/HE_Reforms_Strategy_11_11_2014.pdf.

8. Tragner, J. (2017). $\bar{R} D E C$ (research and development expenditure credit). Retrieved from https://forrestbrown.co.uk/news/rdec-scheme-explained/.

9. Vyshcha osvita v Ukraini u 2017 rotsi. (2018). Statystychnyi zbirnyk Derzhavna sluzhba Statystyky Ukrainy. Vziato z http://www.ukrstat.gov.ua/druk/publicat/kat_u/publosvita u.htm.

10. Vashchenko, L., Kupets, O., Likarchuk, I., \& Sydorenko, M. (2012). Zahalna serednia osvita Ukrainy $v$ konteksti mizhnarodnykh indykatoriv: analitychna dopovid. Kyiv: Tsentr testovykh tekhnolohii i monitorynhu yakosti osvity. 